\title{
Completion of a Chlorination Test Using 250 grams of High-Burnup Used Fuel Cladding from a North Anna Pressurized Water Reactor
}

\section{Fuel Cycle Research \& Development}

Prepared for

U.S. Department of Energy

Fuel Cycle Research and Development E. D. Collins, T. D. Hylton, G. D. Del Cul, B. B. Spencer, R. D. Hunt, and J. A. Johnson

Oak Ridge National Laboratory

30-June-2017

NTRD-MRWFD-2017-000187

ORNL/LTR-2017/327

M3FT-17OR030105062

Approved for public release. Distribution is unlimited.

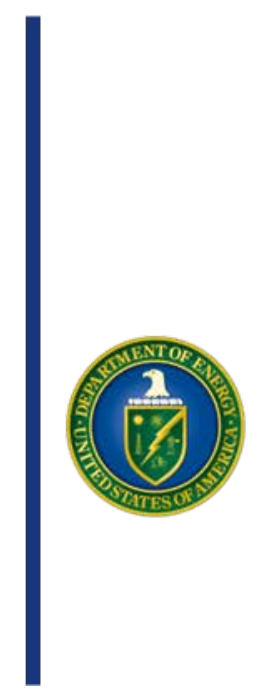




\section{DOCUMENT AVAILABILITY}

Reports produced after January 1, 1996, are generally available free via US Department of Energy (DOE) SciTech Connect.

Website http://www.osti.gov/scitech/

Reports produced before January 1, 1996, may be purchased by members of the public from the following source:

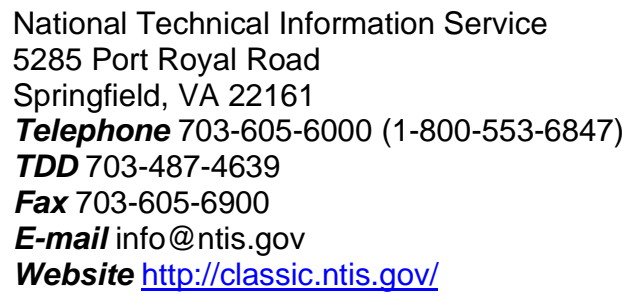

Reports are available to DOE employees, DOE contractors, Energy Technology Data Exchange representatives, and International Nuclear Information System representatives from the following source:

Office of Scientific and Technical Information

PO Box 62

Oak Ridge, TN 37831

Telephone 865-576-8401

Fax 865-576-5728

E-mail reports@osti.gov

Website http://www.osti.gov/contact.html

\section{DISCLAIMER}

This information was prepared as an account of work sponsored by an agency of the U.S. Government. Neither the U.S. Government nor any agency thereof, nor any of their employees, makes any warranty, expressed or implied, or assumes any legal liability or responsibility for the accuracy, completeness, or usefulness, of any information, apparatus, product, or process disclosed, or represents that its use would not infringe privately owned rights. References herein to any specific commercial product, process, or service by trade name, trade mark, manufacturer, or otherwise, does not necessarily constitute or imply its endorsement, recommendation, or favoring by the U.S. Government or any agency thereof. The views and opinions of authors expressed herein do not necessarily state or reflect those of the U.S. Government or any agency thereof. 


\section{CONTENTS}

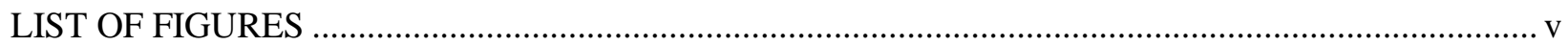

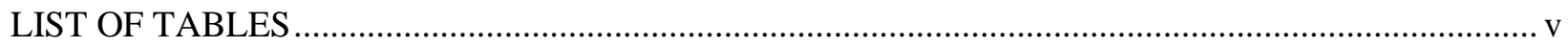

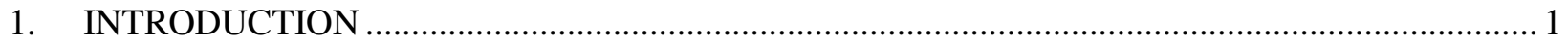

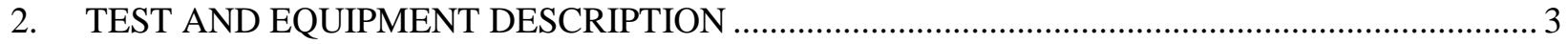

3. COMPOSITION OF ZIRCONIUM ALLOY-CLADDING AND USED NUCLEAR FUEL

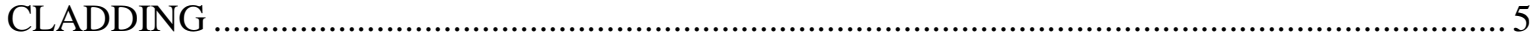

4. $\quad$ PREVIOUS CHLORINATION TESTS AND RESULTS …....................................................... 7

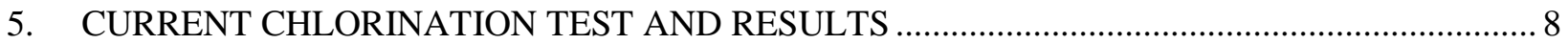

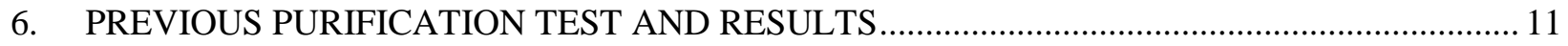

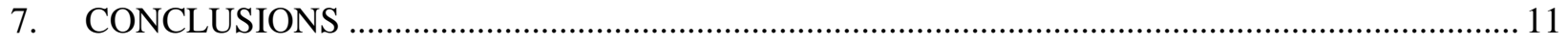

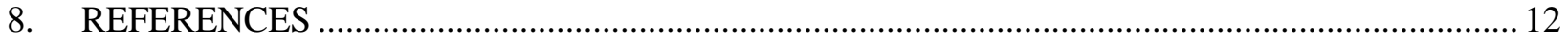


Completion of a Chlorination Test Using 250 grams of High-Burnup Used Fuel Cladding from a North Anna Pressurized Water Reactor

This page is intentionally left blank. 


\section{LIST OF FIGURES}

Figure 1. Recycle of $\mathrm{Zr}$ from cladding is a major element of waste reduction.......................................... 1

Figure 2. Conceptual process steps for Zr recovery from cladding. .......................................................... 2

Figure 3. New metal test equipment for hot cell tests with 100-500 g UNF cladding per test. .................. 3

Figure 4. Zr chlorination test equipment in hot cell.................................................................................... 4

Figure 5. Flowsheet for Zr chlorination tests......................................................................................... 4

Figure 6. Decay of radioactivity in UNF cladding (H. B. Robinson reactor UNF, 22 GWd/MT)............. 6

Figure 7. Vapor pressure of major Zr alloy components and radionuclide impurities. .............................. 7

\section{LIST OF TABLES}

Table 1. Bounding of UNF Zr cladding chlorination tests.................................................................... 1

Table 2. Representative composition of Zr alloy-cladding .................................................................... 5

Table 3. Typical radioactive component concentrations in UNF cladding............................................... 6

Table 4. Results of feasibility tests using $15 \mathrm{~g}$ amounts of lower burnup, longer-decayed Zircaloy2 BWR UNF cladding ${ }^{(a)}$

Table 5. Results from test made with high burnup, shorter-decayed North Anna PWR UNF high-

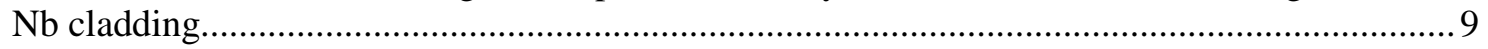

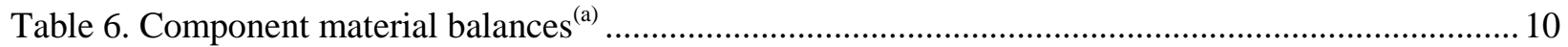

Table 7. Nonradioactive purification test summary …............................................................................. 11 
Completion of a Chlorination Test Using 250 grams of High-Burnup Used Fuel Cladding from a North Anna Pressurized Water Reactor

This page is intentionally left blank. 


\section{COMPLETION OF A CHLORINATION TEST USING 250 GRAMS OF HIGH-BURNUP USED FUEL CLADDING FROM A NORTH ANNA PRESSURIZED WATER REACTOR (MILESTONE M3FT- 170R030105062, DUE JUNE 30, 2017)}

\section{INTRODUCTION}

A second large-scale chlorination test was completed in February 2017 by chlorinating $250 \mathrm{~g}$ of used nuclear fuel (UNF) cladding from a North Anna pressurized water reactor (PWR). Analytical results and a $\mathrm{Zr}$ mass balance from this test are described and compared with previous results obtained by the Zirconium Recovery and Recycle Project. Zr recovery/chlorination purification tests have now been completed with actual UNF cladding that bound the irradiation, decay time, and cladding types typically used today, as indicated in Table 1.

Table 1. Bounding of UNF Zr cladding chlorination tests

\begin{tabular}{|l|c|c|c|}
\hline & Lower bound & Typical & Upper bound \\
\hline Reactor and type & Dresden BWR & BWRs/PWRs & North Anna PWR \\
\hline Burnup (GWd/MT) & 24 & $45-55$ & $63-70$ \\
\hline Decay time (y) & 35 & $5-10$ & 13 \\
\hline Cladding type & Zircaloy-2 & Zircaloy-4/High-Nb & High-Nb \\
\hline
\end{tabular}

Note: BWR = boiling water reactor; PWR = pressurized water reactor.

The second largest element by mass ( $25 \mathrm{wt} . \%$ ) in UNF is the $\mathrm{Zr}$ that is present in the cladding, as indicated in Figure 1 for the average UNF inventory in the United States.

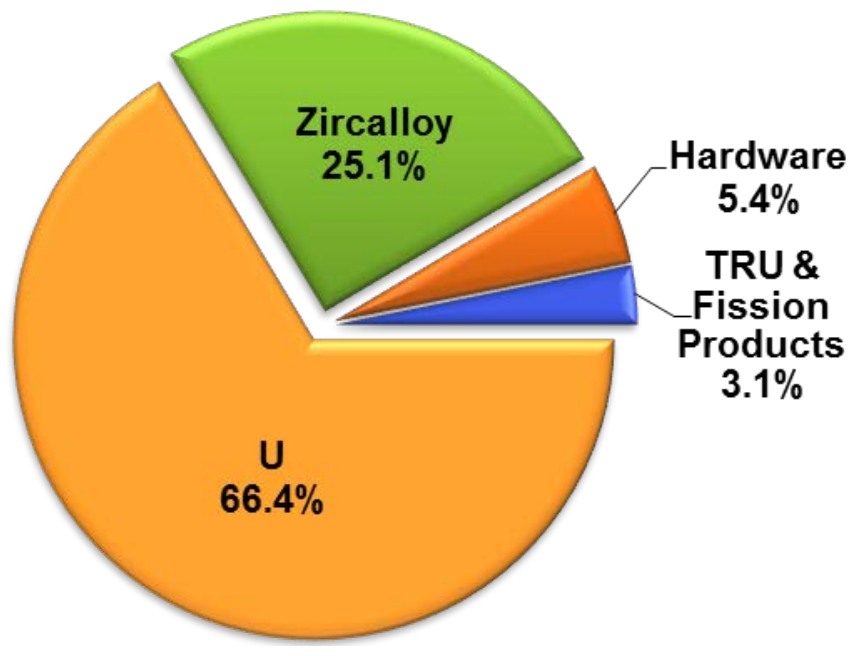

Figure 1. Recycle of $\mathrm{Zr}$ from cladding is a major element of waste reduction.

In current reprocessing practice, the cladding is grouted or compacted and is a large volume fraction of waste requiring disposal in a geologic repository. Since repository space is very expensive, a major 
element of cost and waste reduction would be the recovery, purification, and recycle of Zr in UNF cladding.

An advanced head-end dry pyrochemical chlorination process (Figure 2) is being developed to recover, purify, and possibly recycle the valuable Hf-free $\operatorname{Zr~}(\$ 30-\$ 40 / \mathrm{kg})$, while keeping the costs of the recovery process below those for current compaction treatment and disposal.

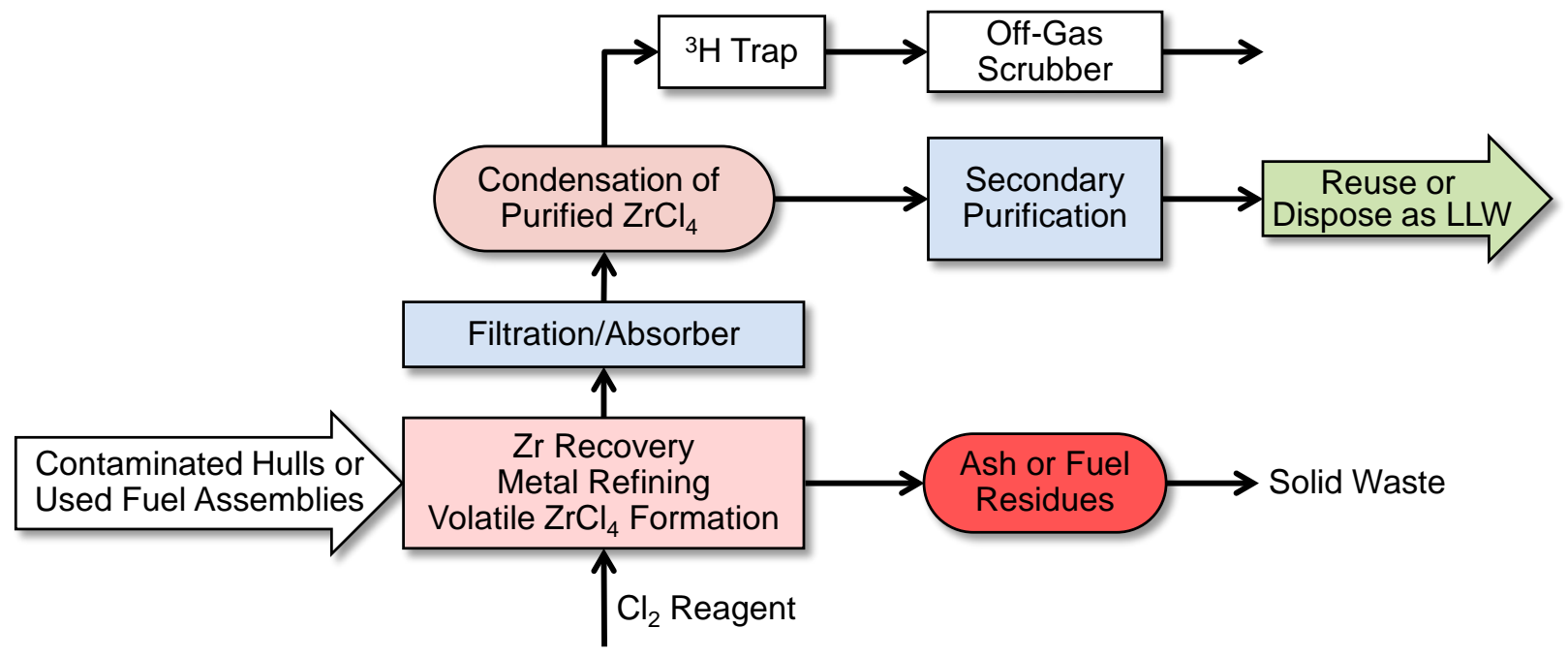

Figure 2. Conceptual process steps for $\mathrm{Zr}$ recovery from cladding.

Process conditions require initially heating to raise the temperature of the cladding in the reactor to above the $\mathrm{ZrCl}_{4}$ sublimation temperature $\left(\sim 320^{\circ} \mathrm{C}\right)$. The reaction between $\mathrm{Cl}$ and $\mathrm{Zr}$ is exothermic:

$$
\mathrm{Zr}+2 \mathrm{Cl}_{2} \rightarrow \mathrm{ZrCl}_{4} \quad \Delta \mathrm{H}=-868 \mathrm{~kJ} / \mathrm{mol}
$$

As $\mathrm{Cl}_{2}$ is introduced, its flow rate is controlled to limit the maximum temperature. The maximum rate of reaction is dependent on the external cooling capability. The reaction rate can be retarded in proportion to the thickness of oxide layer on the surface of the cladding. The heavy, gaseous $\mathrm{ZrCl}_{4}$ product salt is transported through a heated pipe to a condenser where desublimation occurs and a solid salt product is obtained. Product purity is affected by the relative volatility of impurity species.

The recovered product must contain lowered impurity concentrations that (1) would allow disposal as low-level waste, or (2) would be inconsequential to use in future nuclear applications, recognizing that the recovered $\mathrm{Zr}$ will inherently contain ${ }^{93} \mathrm{Zr}$ (half-life $=1.5$ million years and a weak $§$ radiation emitter). Consequently, the challenge is to remove (1) radioactive impurities, which include uranium, transuranium elements, fission products, and activation products other than ${ }^{93} \mathrm{Zr}$; (2) chemical alloy metals, which include $\mathrm{Sn}, \mathrm{Nb}, \mathrm{Fe}, \mathrm{Cr}$, and $\mathrm{Ni}$; and (3) nonmetals $\mathrm{O}, \mathrm{C}$, and $\mathrm{N}$.

Both nonradioactive process development tests and radioactive feasibility tests with actual UNF cladding have been made in laboratory glassware to determine (1) optimum processing conditions, (2) optimum equipment configuration (gas up-flow, down-flow, or horizontal flow), and (3) the chemical and radiochemical purity of the $\mathrm{ZrCl}_{4}$ product salt. Emphasis is still on product purity with new attention to the use of new metal equipment to enable scale-up to process 100-500 g of cladding (producing $250 \mathrm{~g}$ to $>1 \mathrm{~kg}$ of product salt) per batch and to enable heavily shielded hot cell tests using higher burnup and shorter-cooled UNF cladding. 


\section{TEST AND EQUIPMENT DESCRIPTION}

During FY 2015-2016, the new larger-scale metal construction test assembly (Figures 3 and 4) was designed, fabricated, instrumented, cold-tested in the laboratory, and installed into the shielded hot cell, where an initial hot test was made with actual UNF cladding. The design is a horizontal reactor with downward gas-flow through a bed of cladding supported by a perforated plate. The sublimed, gaseous $\mathrm{ZrCl}_{4}$ product flows horizontally through a filter/absorber assembly into a vertical condenser for desublimation into a dry salt product. An external vibrator is attached to the condenser to help direct the dry salt flow into a replaceable glass bottle collector. The reactor is electrically heated by several mantles and tapes, and four thermocouples are located across the length of the reactor to provide a temperature profile. Also, the reactor is equipped with a charging door and a removable metal boat for collection of unreacted cladding and residual ash. The filter/absorber is attached to the boat so that it can be removed, cleaned, and recharged.
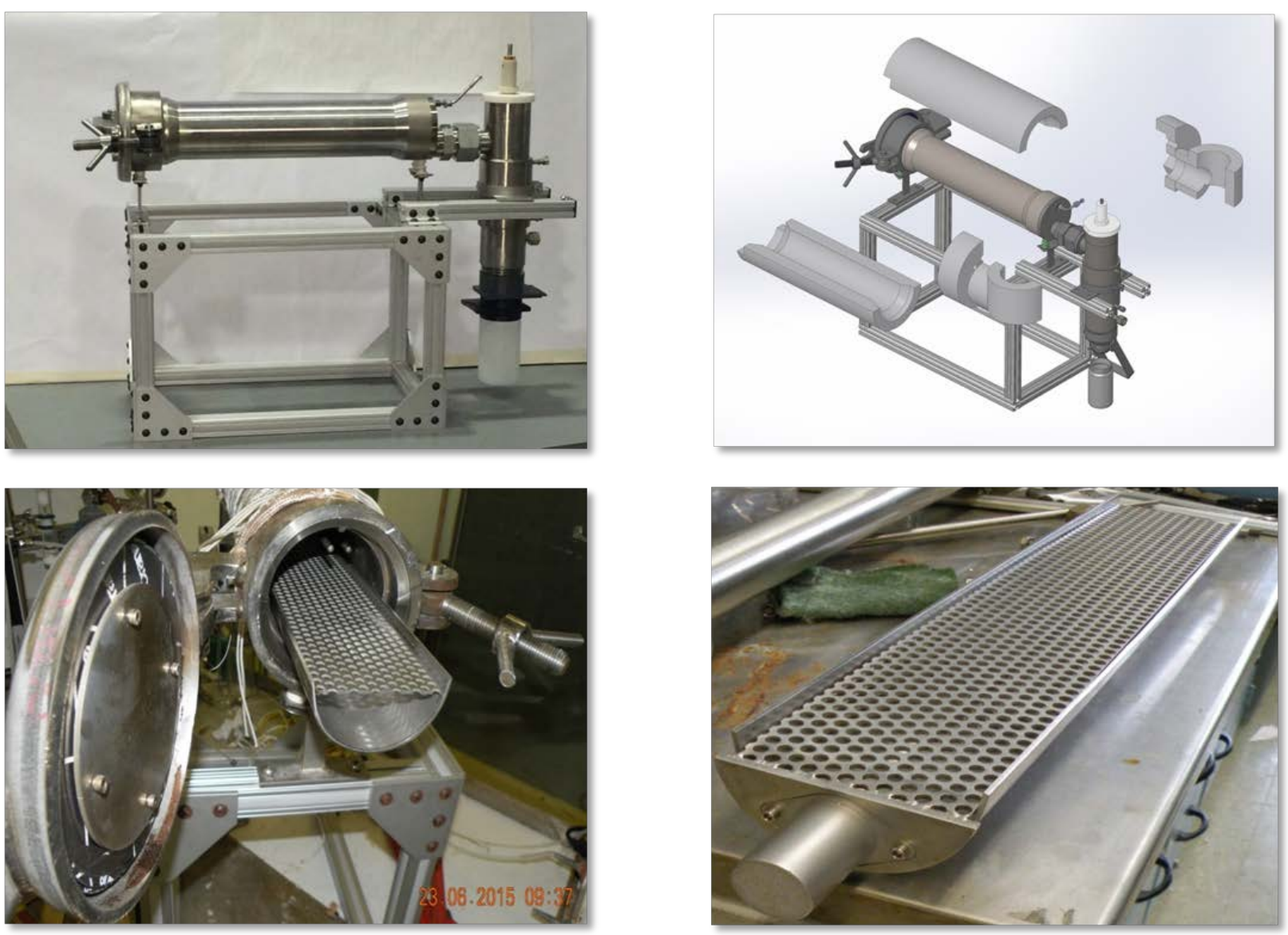

Figure 3. New metal test equipment for hot cell tests with 100-500 g UNF cladding per test. 


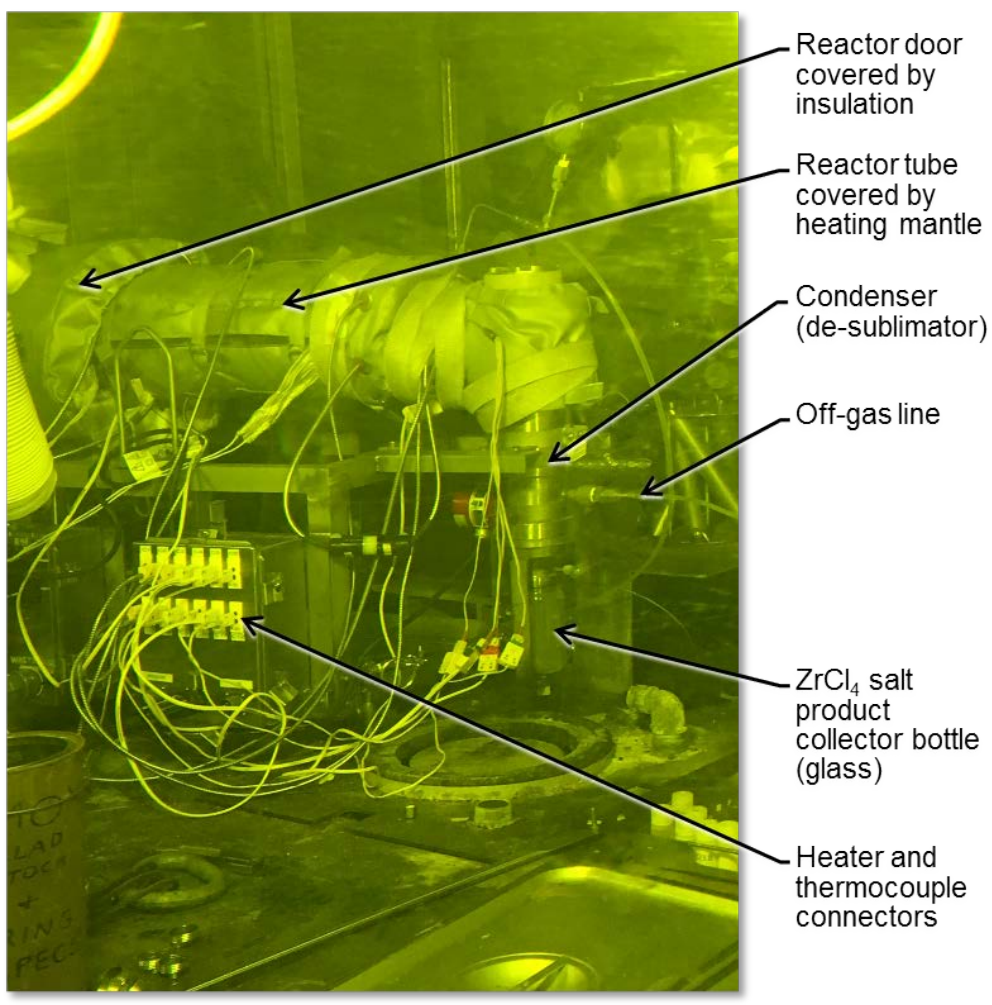

Figure 4. Zr chlorination test equipment in hot cell.

The equipment flowsheet is illustrated in Figure 5, although the tritium trap in the condenser off-gas line was not used in the test made in February 2017.

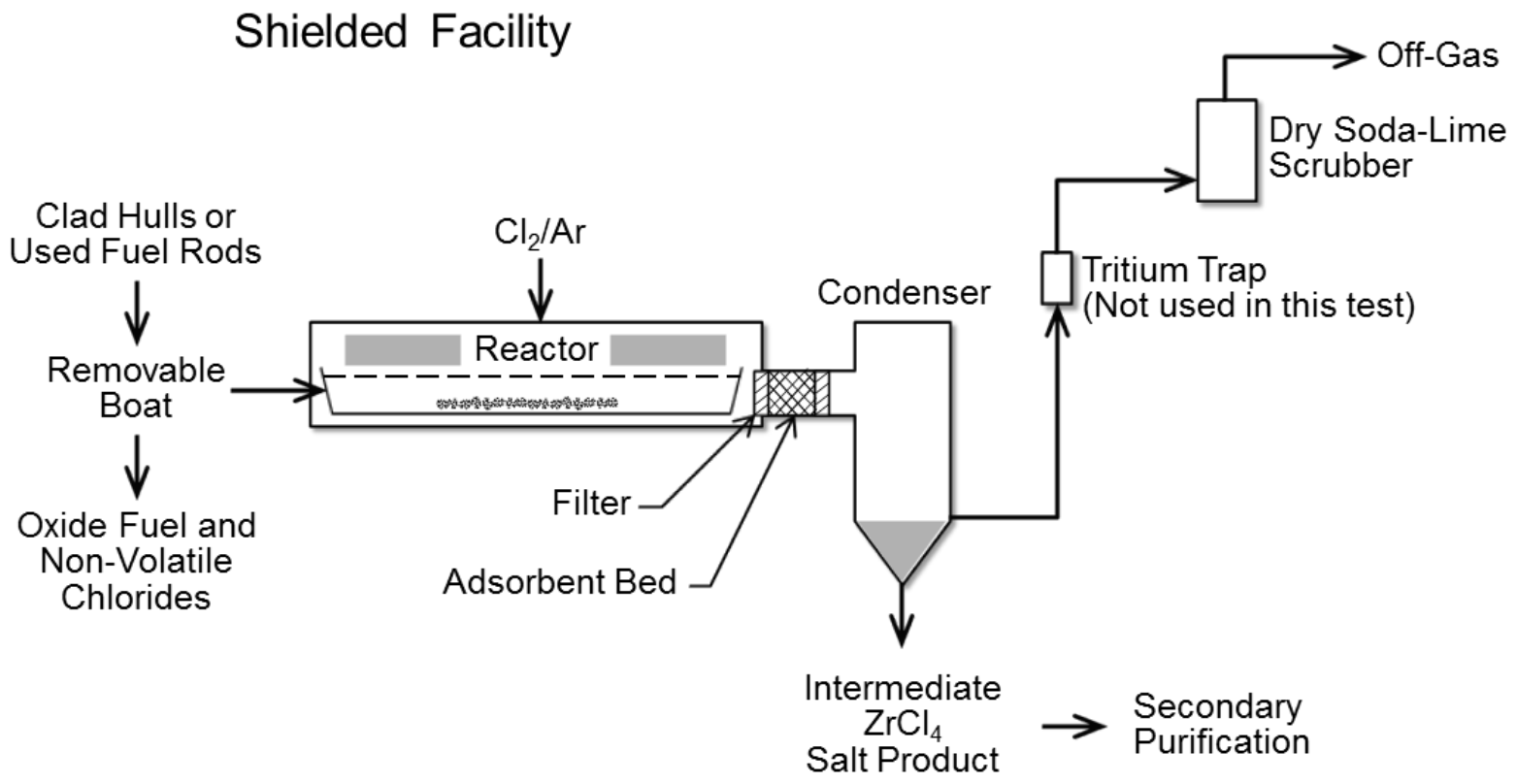

Figure 5. Flowsheet for $\mathrm{Zr}$ chlorination tests. 
Because of its inexpensive cost and ease of construction, 316 stainless steel was selected for use in the equipment fabrication, although it can be corroded by wet $\mathrm{Cl}_{2}$. Stainless steel does not corrode in dry $\mathrm{Cl}_{2}$, and the operating procedure includes a predrying step with Ar gas at elevated temperature. This test reactor is the initial design and does not have any external heat removal capability for the exothermic chlorination reactor; therefore, the $\mathrm{Cl}_{2}$ flow rate is controlled to limit the rate of the reaction and heat generated.

\section{COMPOSITION OF ZIRCONIUM ALLOY-CLADDING AND USED NUCLEAR FUEL CLADDING}

The typical elemental concentrations in Hf-free, nuclear-grade, $\mathrm{Zr}$ alloy-cladding, and UNF cladding are shown in Tables 2 and 3.

Table 2. Representative composition of $\mathrm{Zr}$ alloy-cladding

\begin{tabular}{|c|c|c|c|}
\hline Element & $\begin{array}{c}\text { Zircaloy-2 } \\
\mathbf{( p p m )}\end{array}$ & $\begin{array}{c}\text { Zircaloy-4 } \\
\mathbf{( p p m )}\end{array}$ & $\begin{array}{c}\text { High-Nb Zircaloy } \\
\mathbf{( p p m )}\end{array}$ \\
\hline $\mathrm{Sn}$ & 14,200 & 12,900 & $<35$ \\
\hline $\mathrm{Nb}$ & $<50$ & $<50$ & 10,100 \\
\hline $\mathrm{Fe}$ & 1,720 & 2,140 & 400 \\
\hline $\mathrm{Cr}$ & 1,020 & 1,110 & $<50$ \\
\hline $\mathrm{Ni}$ & 690 & $<35$ & $<35$ \\
\hline $\mathrm{O}$ & 1,320 & 1,180 & 1,370 \\
\hline $\mathrm{C}$ & 130 & 140 & 47 \\
\hline $\mathrm{N}$ & 42 & 39 & 33 \\
\hline $\mathrm{Si}$ & 91 & 96 & $<25$ \\
\hline $\mathrm{Al}$ & 45 & 54 & $<3$ \\
\hline $\mathrm{P}$ & $<3$ & 7 & 21 \\
\hline $\mathrm{S}$ & $<10$ & Not measured & $<1$ \\
\hline $\mathrm{U}$ & $<1$ & $<1$ & 41 \\
\hline
\end{tabular}

*Samples and compositions provided by Allegheny Technologies Industries. Balance of each type is Zr.

For UNF cladding, the component concentrations change with the burnup of the UNF and the decay time following discharge from the irradiation reactor ("cooling time"). Figure 6 illustrates typical changes in radionuclide composition and concentrations with increasing burnup and different decay times. Table 3 compares data published ${ }^{\mathrm{R} 1}$ by the French Alternative Energies and Atomic Energy Commission for UNF cladding that had a burnup of $36 \mathrm{GWd} / \mathrm{MT}$ and decayed for 5 years (the typical time that UNF is reprocessed in the French reprocessing plant) with data measured at the Oak Ridge National Laboratory (ORNL) for cladding samples from a Dresden BWR UNF that had a burnup of $24 \mathrm{GWd} / \mathrm{MT}$ and a decay time of 38 years and with cladding samples from the North Anna PWR that had a burnup of 63$70 \mathrm{GWd} / \mathrm{MT}$ and a decay time of 13 years. 
Completion of a Chlorination Test Using 250 grams of High-Burnup Used Fuel Cladding from a North Anna Pressurized Water Reactor

Table 3. Typical radioactive component concentrations in UNF cladding

\begin{tabular}{|l|c|c|c|}
\hline \multicolumn{1}{|c|}{ Cladding type } & Not specified $^{\text {(a) }}$ & Zircaloy-2 $^{(\mathbf{b})}$ & High-Nb $^{(\mathbf{b})}$ \\
\hline Burnup & $36 \mathrm{GWd} / \mathrm{MT}$ & $24 \mathrm{GWd} / \mathrm{MT}$ & $63-70 \mathrm{GWd} / \mathrm{MT}$ \\
\hline Decay time & $5 \mathrm{y}$ & $38 \mathrm{y}$ & $13 \mathrm{y}$ \\
\hline $\mathrm{U}(\mu \mathrm{g} / \mathrm{g} \mathrm{Zr})$ & 77 & - & 610 \\
\hline $\mathrm{Pu}(\mu \mathrm{g} / \mathrm{g} \mathrm{Zr})$ & 3.3 & 0.77 & 34 \\
\hline${ }^{244} \mathrm{Cm}(\mathrm{Bq} / \mathrm{g} \mathrm{Zr})$ & $3.7 \mathrm{E}+4$ & $4.2 \mathrm{E}+4$ & $1.1 \mathrm{E}+6$ \\
\hline${ }^{241} \mathrm{Am}(\mathrm{Bq} / \mathrm{g} \mathrm{Zr})$ & - & $3.9 \mathrm{E}+4$ & $2.0 \mathrm{E}+5$ \\
\hline${ }^{137} \mathrm{Cs}(\mathrm{Bq} / \mathrm{g} \mathrm{Zr})$ & $2.5 \mathrm{E}+7$ & $6.0 \mathrm{E}+6$ & $4.6 \mathrm{E}+7$ \\
\hline${ }^{125} \mathrm{Sb}(\mathrm{Bq} / \mathrm{g} \mathrm{Zr})$ & - & - & $9.6 \mathrm{E}+5$ \\
\hline${ }^{60} \mathrm{Co}(\mathrm{Bq} / \mathrm{g} \mathrm{Zr})$ & - & $3.7 \mathrm{E}+4$ & $1.8 \mathrm{E}+5$ \\
\hline${ }^{154} \mathrm{Eu}(\mathrm{Bq} / \mathrm{g} \mathrm{Zr})$ & - & $1.5 \mathrm{E}+4$ & $3.2 \mathrm{E}+5$ \\
\hline${ }^{94} \mathrm{Nb} \mathrm{(Bq/g} \mathrm{Zr)}$ & - & - & $1.4 \mathrm{E}+6$ \\
\hline
\end{tabular}

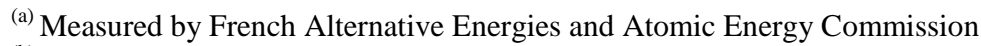

(b) Measured by ORNL

The radioactivity in typical UNF cladding hulls is sufficiently high to require designation as “intermediate-level waste” in Europe and "greater-than-Class C” waste in the United States, requiring relatively expensive disposal by means of emplacement into a geologic repository. Previous efforts made in various research programs to develop a method of decontamination of UNF cladding have been unsuccessful, primarily because the radionuclides have been embedded within the cladding walls by fission product recoil. Both Table 3 and Figure 6 show that the major radiation emitted from UNF cladding is from ${ }^{137} \mathrm{Cs}$, except during the initial decay period of $<5$ years when emissions from ${ }^{125} \mathrm{Sb}$ and other short-lived fission and activation product radionuclides are major contributors.

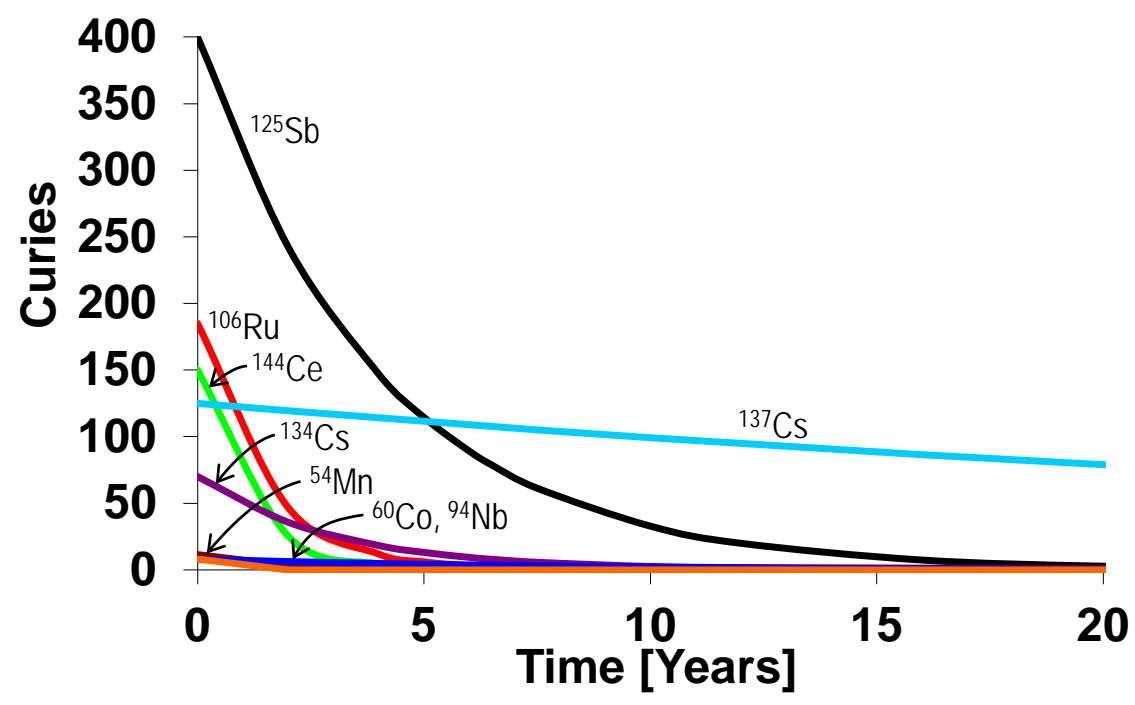

Figure 6. Decay of radioactivity in UNF cladding (H. B. Robinson reactor UNF, 22 GWd/MT). 


\section{PREVIOUS CHLORINATION TESTS AND RESULTS}

Previous tests and analyses ${ }^{\mathrm{R} 2}$ for this project have shown that the $\mathrm{Zr}$ contained in UNF cladding can be separated and purified from most of the radioactive and nonradioactive impurity elements by converting the $\mathrm{Zr}$ to volatile $\mathrm{ZrCl}_{4}$ salt, which sublimes to a vapor at $\sim 330^{\circ} \mathrm{C}$ and is then condensed to a dry salt product. This is the primary purification process.

Also, previous nonradioactive and radioactive chlorination tests, together with thermodynamic analyses and volatility reference data (Figure 7), have shown that fuel components such as $U$ and Pu are present as oxides and not chlorinated. In contrast, fission and activation product radionuclides and $\mathrm{Zr}$ alloy chemical elements can form chloride species that are more, less, or similar to the volatility of $\mathrm{ZrCl}_{4}$.

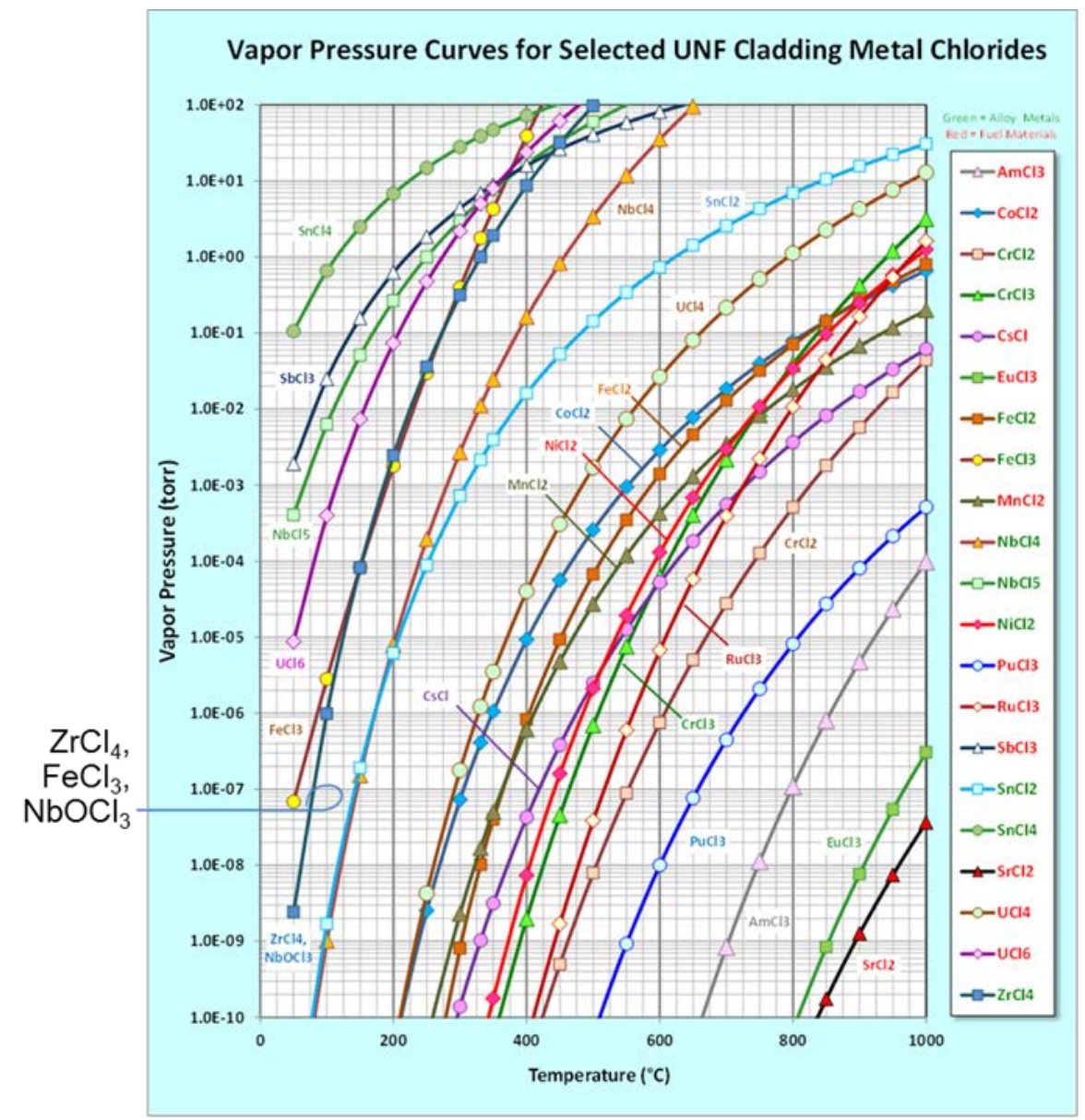

Figure 7. Vapor pressure of major $\mathrm{Zr}$ alloy components and radionuclide impurities. ${ }^{(\mathrm{R} 3)}$

The results from feasibility tests (Table 4) made with $\sim 15 \mathrm{~g}$ of the Dresden boiling water reactor (BWR) UNF Zircaloy-2 cladding indicated that the $\mathrm{ZrCl}_{4}$ product salt could be handled without shielding. 
Table 4. Results of feasibility tests using $15 \mathrm{~g}$ amounts of lower burnup, longer-decayed Zircaloy-2 BWR UNF cladding $^{(a)}$

\begin{tabular}{|c|c|c|c|c|c|c|}
\hline \multirow[b]{2}{*}{ Nuclide } & \multicolumn{3}{|c|}{$\begin{array}{c}\text { Hulls from fuel dissolution in } \mathrm{HNO}_{3} \\
\text { chlorination } \\
(2012)\end{array}$} & \multicolumn{3}{|c|}{$\begin{array}{l}\text { Chemical decladding chlorination } \\
\text { (August 2013) }\end{array}$} \\
\hline & $\begin{array}{l}\text { Cladding feed } \\
\text { (Bq/g) }\end{array}$ & $\begin{array}{c}\mathrm{ZrCl}_{4} \\
\text { product } \\
(\mathrm{Bq} / \mathrm{g})\end{array}$ & $\begin{array}{l}\text { Decon. } \\
\text { factor }\end{array}$ & $\begin{array}{c}\text { Fuel and } \\
\text { clad feed } \\
(\mathrm{Bq} / \mathrm{g})\end{array}$ & $\begin{array}{c}\mathrm{ZrCl}_{4} \\
\text { product } \\
(\mathrm{Bq} / \mathrm{g})\end{array}$ & $\begin{array}{l}\text { Decon. } \\
\text { factor }\end{array}$ \\
\hline${ }^{241} \mathrm{Am}$ & $1.2 \mathrm{E}+4$ & $<2.5 \mathrm{E}+2$ & $>48$ & $1.8 \mathrm{E}+8$ & $9.4 \mathrm{E}+4$ & 1,900 \\
\hline${ }^{243} \mathrm{Am}$ & - & - & - & $3.8 \mathrm{E}+6$ & $<5.1 \mathrm{E}+1$ & $>75,000$ \\
\hline${ }^{244} \mathrm{Cm}$ & $2.2 \mathrm{E}+3$ & $<1.0 \mathrm{E}+3$ & $>2$ & - & - & - \\
\hline${ }^{137} \mathrm{Cs}$ & $1.5 \mathrm{E}+7$ & $8.3 \mathrm{E}+3$ & $\begin{array}{l}1,800 \\
-\end{array}$ & $2.7 \mathrm{E}+9$ & $3.6 \mathrm{E}+3$ & 750,000 \\
\hline${ }^{125} \mathrm{Sb}$ & (b) & (b) & - & (b) & $4.7 \mathrm{E}+2$ & - \\
\hline${ }^{94} \mathrm{Nb}$ & (b) & $2.0 \mathrm{E}+3$ & - & (b) & (b) & - \\
\hline${ }^{60} \mathrm{Co}$ & $2.7 \mathrm{E}+4$ & $<1.3 \mathrm{E}+2$ & $>200$ & $<4.0 \mathrm{E}+5$ & $<5.5 \mathrm{E}+1$ & $(7,300)$ \\
\hline${ }^{154} \mathrm{Eu}$ & $2.1 \mathrm{E}+4$ & $<2.2 \mathrm{E}+2$ & $>95$ & $1.2 \mathrm{E}+7$ & $<7.4 \mathrm{E}+1$ & $>170,000$ \\
\hline${ }^{155} \mathrm{Eu}$ & (b) & (b) & - & (b) & $6.3 \mathrm{E}+1$ & - \\
\hline Gross $\beta$ & $1.5 \mathrm{E}+7$ & $5.4 \mathrm{E}+4$ & 280 & (b) & (b) & - \\
\hline $\begin{array}{l}\text { Radiation } \\
\text { dose }\end{array}$ & $3 \mathrm{mSv}$ & $<2 \mu S v$ & $>1,500$ & (c) & (c) & - \\
\hline
\end{tabular}

(a) UNF cladding from Dresden-1 BWR, 24 GWd/MT burnup, 37 y decay

(b) Not reported

(c) Not measured

\section{CURRENT CHLORINATION TEST AND RESULTS}

Results from the February 2017 chlorination test (Table 5) made with higher-burnup, shorter-cooled, North Anna PWR-irradiated, high-Nb, UNF cladding show that the product salt will require shielding because it contains significant levels of radioactive ${ }^{94} \mathrm{Nb}$ and ${ }^{125} \mathrm{Sb}$. Even though ${ }^{134-137} \mathrm{Cs}$ is the major radionuclide in the cladding, it is not volatile, and if the $\mathrm{ZrCl}_{4}$ vapor is filtered to remove entrained nonvolatiles, as it was in this test and the previous feasibility tests (Table 4), the Cs is left in the ash residue. But $\mathrm{Nb}\left(\right.$ as $\mathrm{NbOCl}_{3}$, ) has similar volatility as $\mathrm{ZrCl}_{4}$, and $\mathrm{Sb}$ (as $\mathrm{SbCl}_{3}$ ) is even more volatile (Figure 7). Even though Fe and $\mathrm{Cr}$ are significant alloys in Zr-based cladding (Table 2), corrosion of the stainless steel apparatus produced much more $\mathrm{Fe}$ and $\mathrm{Cr}$ than was present in the cladding. 
Table 5. Results from test made with high burnup, shorter-decayed North Anna PWR UNF high-Nb cladding

\begin{tabular}{|c|c|c|c|c|}
\hline & Cladding feed & $\mathrm{ZrCl}_{4}$ product & Product & Residue ash \\
\hline & $(\mathrm{Bq} / \mathrm{g} \mathrm{Zr})$ & $(\mathrm{Bq} / \mathrm{g} \mathrm{Zr})$ & Decon. factor & $(\mathrm{Bq} / \mathrm{g} \mathrm{Zr})$ \\
\hline Gross $\alpha$ & $6.4 \mathrm{E}+6$ & $<1.0 \mathrm{E}+5$ & $>64$ & $1.6 \mathrm{E}+7$ \\
\hline${ }^{238} \mathrm{Pu}^{-241} \mathrm{Am}$ & $4.7 \mathrm{E}+6$ & $<1.0 \mathrm{E}+5$ & $>47$ & $1.3 \mathrm{E}+7$ \\
\hline${ }^{244} \mathrm{Cm}$ & $1.7 \mathrm{E}+6$ & & & $1.7 \mathrm{E}+6$ \\
\hline \multicolumn{5}{|l|}{$\gamma$ spectroscopy } \\
\hline${ }^{241} \mathrm{Am}$ & $3.1 \mathrm{E}+5$ & $<2.8 \mathrm{E}+4$ & $>11$ & $<2.6 \mathrm{E}+6$ \\
\hline${ }^{243} \mathrm{Am}$ & $4.6 \mathrm{E}+4$ & $<8.4 \mathrm{E}+3$ & $>5$ & $<6.2 \mathrm{E}+5$ \\
\hline${ }^{137} \mathrm{Cs}$ & $7.2 \mathrm{E}+7$ & $3.8 \mathrm{E}+4$ & 1895 & $9.2 \mathrm{E}+8$ \\
\hline${ }^{134} \mathrm{Cs}$ & $2.2 \mathrm{E}+6$ & $<1.1 \mathrm{E}+4$ & $>200$ & $2.9 \mathrm{E}+7$ \\
\hline${ }^{94} \mathrm{Nb}$ & $2.2 \mathrm{E}+6$ & $1.7 \mathrm{E}+6$ & 1.3 & $1.4 \mathrm{E}+6$ \\
\hline${ }^{125} \mathrm{Sb}$ & $9.6 \mathrm{E}+5$ & $3.7 \mathrm{E}+5$ & 2.5 & $<2.0 \mathrm{E}+6$ \\
\hline${ }^{154} \mathrm{Eu}$ & $5.0 \mathrm{E}+5$ & $<1.2 \mathrm{E}+4$ & $>41$ & $8.7+E 5$ \\
\hline${ }^{155} \mathrm{Eu}$ & $1.2 \mathrm{E}+5$ & $<1.3 \mathrm{E}+4$ & $>9$ & $<7.6 \mathrm{E}+5$ \\
\hline${ }^{60} \mathrm{Co}$ & $2.8 \mathrm{E}+5$ & $<7.7 \mathrm{E}+3$ & $>36$ & $2.9 \mathrm{E}+6$ \\
\hline ICP-MS & $(\mu \mathrm{g} / \mathrm{g} \mathrm{Zr})$ & $(\mu \mathrm{g} / \mathrm{g} \mathrm{Zr})$ & & $(\mu \mathrm{g} / \mathrm{g} Z \mathrm{Zr})$ \\
\hline $\mathrm{U}$ & 610 & 62 & 10 & 6,224 \\
\hline $\mathrm{Pu}$ & 34 & $<3$ & 11 & 225 \\
\hline $\mathrm{Np}$ & 35 & 3 & 10 & 26 \\
\hline $\mathrm{Am}$ & 4 & $<1$ & $>4$ & $<26$ \\
\hline $\mathrm{Nb} /{ }^{93} \mathrm{Zr}$ & 14,400 & 17,091 & $<1$ & 10,530 \\
\hline Sn & 48 & 17 & 3 & 265 \\
\hline $\mathrm{Fe}$ & 1,510 & $44,025^{(\mathrm{a})}$ & $<<1$ & $5,181^{(a)}$ \\
\hline $\mathrm{Cr}$ & 77 & $431^{(\mathrm{a})}$ & $<<1$ & $4,565^{(a)}$ \\
\hline $\mathrm{Ni}$ & $<75$ & $<74^{(\mathrm{a})}$ & 1 & $2,989^{(a)}$ \\
\hline Mo & 1,740 & 1,467 & 1 & 2,124 \\
\hline${ }^{99} \mathrm{Tc}$ & 81 & 32 & 3 & 364 \\
\hline $\mathrm{Al}$ & $<150$ & $<150$ & 1 & 4,746 \\
\hline $\mathrm{Hf}$ & $<75$ & $<74$ & 1 & $<99$ \\
\hline$\beta-\gamma$ radiation & (Sv/g Zr) & $(\mathrm{Sv} / \mathrm{g} \mathrm{Zr})$ & & (Sv/g Zr) \\
\hline At contact ( 2 in.) & 2.3 & 0.25 & 9 & 34.3 \\
\hline
\end{tabular}

(a) Contains stainless steel corrosion products

(b) ICP-MS = inductively coupled plasma mass spectrometry

Still, the behavior of Fe was evident as it has been determined in previous experiments (Fe is present initially as relatively nonvolatile $\mathrm{FeCl}_{2}$, but is oxidized during the batch chlorination to volatile $\mathrm{FeCl}_{3}$ ). Figure 7 does not indicate a relatively volatile species of $\mathrm{Cr}$, but results of this test indicate a similar oxidation effect as Fe. Thus, Fe and $\mathrm{Cr}$ are the major nonradioactive impurities in the $\mathrm{ZrCl}_{4}$ salt product and ${ }^{94} \mathrm{Nb}$ and ${ }^{125} \mathrm{Sb}$, are the major radionuclide impurities.

For the February 2017 chlorination test, $250 \mathrm{~g}$ of North Anna cladding was fed, and $10 \mathrm{~g}$ of unreacted cladding was recovered. Thus, $240 \mathrm{~g}$ was chlorinated. The component mass balances (Table 6) show that 
78\% of the $\mathrm{Zr}$ was recovered, $70 \%$ in the $\mathrm{ZrCl}_{4}$ salt product, and $7.6 \%$ (apparently $\mathrm{ZrO}_{2}$ ) in the ash residue). Some of the $\mathrm{Zr}$ is contained in the inductively coupled plasma mass spectrometry analysis for $\mathrm{Nb}\left(\right.$ as ${ }^{93} \mathrm{Nb}+{ }^{93} \mathrm{Zr}$ ), so the $\mathrm{ZrCl}_{4}$ salt product likely contained a greater amount of $\mathrm{Zr}$ than $70 \%$ (the exact amount could not be determined). The remaining $\mathrm{Zr}$ was likely retained in the test apparatus.

Table 6. Component material balances ${ }^{(a)}$

\begin{tabular}{|c|r|r|r|}
\hline $\begin{array}{c}\text { Component } \\
\text { recovery }\end{array}$ & $\begin{array}{c}\text { In salt product } \\
\mathbf{( \% )}\end{array}$ & $\begin{array}{c}\text { In ash residue } \\
\text { (\%) }\end{array}$ & $\begin{array}{c}\text { Total } \\
\text { (\%) }\end{array}$ \\
\hline $\mathrm{Zr}^{(\mathrm{b})}$ & 70 & 7.6 & 78 \\
\hline${ }^{137} \mathrm{Cs}^{(\mathrm{c})}$ & 0.4 & 97 & 97 \\
\hline${ }^{134} \mathrm{Cs}^{(\mathrm{c})}$ & $<0.4$ & 99.7 & $\sim 100$ \\
\hline $\mathrm{Nb} /{ }^{93} \mathrm{Zr}^{(\mathrm{c})}$ & 83 & 5.6 & 89 \\
\hline${ }^{94} \mathrm{Nb}^{(\mathrm{c})}$ & 54 & 4.8 & 59 \\
\hline${ }^{125} \mathrm{Sb}^{(\mathrm{c})}$ & 27 & $<16$ & $24-43$ \\
\hline $\mathrm{Mo}$ & 59 & 9 & 68 \\
\hline $\mathrm{Sn}^{(\mathrm{d})}$ & 25 & 42 & 67 \\
\hline $\mathrm{U}$ & 7 & 40 & 47 \\
\hline $\mathrm{Pu}^{(\mathrm{d})}$ & $<6$ & 50 & $50-56$ \\
\hline $\mathrm{Cr}^{(\mathrm{d})(\mathrm{e})}$ & 395 & 452 & 846 \\
\hline $\mathrm{Fe}^{(\mathrm{c})(\mathrm{e})}$ & 2,043 & 26 & 2,070 \\
\hline$\beta-\gamma \mathrm{radiation}^{(\mathrm{f})}$ & 8 & 113 & 121 \\
\hline
\end{tabular}

(a) Based on weights and sample analysis

(b) Major component in cladding (98.8\% wt.)

(c) Major impurity

(d) Minor impurity

(e) Corrosion product of stainless steel

(f) At contact ( 2 in.)

Table 6 also shows the metal impurity mass and radionuclide activity balances, which are generally consistent with previously determined behavior. Most of the radiation dose (primarily ${ }^{134-137} \mathrm{Cs}$ ) was contained in the residue ash. The ${ }^{94} \mathrm{Nb}$ and ${ }^{125} \mathrm{Sb}$ radionuclides in the $\mathrm{ZrCl}_{4}$ salt product made it have a higher dose rate than products from previous tests with Dresden UNF Zircaloy-2 cladding. Therefore, the subsequent purification process will have to be done in a shielded facility.

Since about 1990, high-Nb alloy Zr-based cladding has been used in most PWR fuels, and the burnup rate is $45-55 \mathrm{GWd} / \mathrm{MT}$, which is lower than the North Anna UNF cladding feed tested with the February 2017 chlorination, but that rate is likely high enough to create a significant amount of ${ }^{94} \mathrm{Nb}$. Consequently, much of the UNF cladding produced since 1990 will require both the chlorination and secondary purification to be done in a shielded facility.

The February 2017 chlorination test was made over a 2-day period with interim stoppage of $\mathrm{Cl}_{2}$ feed gas and reduction of the reactor temperature after the first day. Upon resumption of heating, a layer of white powder was collected in the salt product bottle and then the more normal tan-colored powder resumed. Our speculation is that the white powder was the more volatile impurities that had been released during the first day chlorination. During the next chlorination test, we will try a new procedure in which the reactor temperature will be lowered periodically below the sublimation temperature to selectively collect the more volatile impurities. 


\section{PREVIOUS PURIFICATION TEST AND RESULTS}

In 2015, a series of nonradioactive purification tests were made to provide a basis for future studies to select the optimum purification method. Results are shown in Table 7. Column A shows the impurity concentrations in the starting material, which consisted of about $90 \%$ (wt) Zircaloy-2, scrap tubes, and $\sim 10 \%$ high-Nb scrap tubes. This feed material was chlorinated at typical conditions. Column B shows the impurity concentrations in the $\mathrm{ZrCl}_{4}$ product, which was then used as feed to four purification tests, which all included resublimation and recondensation of the $\mathrm{ZrCl}_{4}$. The first purification test was done in a reducing atmosphere of $4 \% \mathrm{H}_{2}$ in $\mathrm{N}_{2}$, and the product impurity concentrations (column C) show that the $\mathrm{Sn}, \mathrm{Cr}$, and Ni were reduced significantly, but the Fe and $\mathrm{Nb}$ were not reduced. The second test used pure $\mathrm{H}_{2}$ (above the upper explosive concentration) as the reducing atmosphere; column D results show the Fe was sufficiently reduced but $\mathrm{Nb}$ was not. The last two tests were made with added $\mathrm{ZrH}_{2}(\sim 2.5 \% \mathrm{wt})$ as the reducing agent, first in an Ar atmosphere (column E results) and then in a $4 \% \mathrm{H}_{2}$ in $\mathrm{N}_{2}$ reducing atmosphere (column F results). Both of the tests made with added $\mathrm{ZrH}_{2}$ successfully removed both Fe and $\mathrm{Nb}$. Apparently the $\mathrm{FeCl}_{3}$ was reduced to nonvolatile $\mathrm{FeCl}_{2}$ and $\mathrm{NbOCl}_{3}$ was reduced to less volatile $\mathrm{NbCl}_{4}$. The results of this series of tests showed that the $\mathrm{ZrCl}_{4}$ product can be successfully purified. Further exploration and optimization of purification methods have been transferred to experts from two university-led Nuclear Energy University Program teams. Their studies have been in progress for almost 2 years now and significant progress has been made. Plans at ORNL are to begin using some of the methods developed to purify the $\mathrm{ZrCl}_{4}$ chlorination product salt. Since the purification of the $\mathrm{ZrCl}_{4}$ from the North Anna UNF cladding test still contains a significant radiation dose, the purification must be done in the shielded hot cell.

Table 7. Nonradioactive purification test summary

\begin{tabular}{|c|c|c|c|c|c|c|}
\hline \multirow{3}{*}{ Column } & $\mathbf{A}$ & B & $\mathrm{C}$ & D & $E$ & $\mathbf{F}$ \\
\hline & $\begin{array}{c}\text { Chlorination } \\
\text { feed }\end{array}$ & $\begin{array}{c}\text { Chlorination } \\
\text { Product }\end{array}$ & $\begin{array}{c}\text { Resublimed } \\
\mathrm{ZrCl}_{4}\end{array}$ & $\begin{array}{c}\text { Resublimed } \\
\mathrm{ZrCl}_{4}\end{array}$ & $\begin{array}{c}\text { Resublimed } \\
\mathrm{ZrCl}_{4}\end{array}$ & $\begin{array}{c}\text { Resublimed } \\
\mathrm{ZrCl}_{4}\end{array}$ \\
\hline & $\begin{array}{c}\text { Clad } \\
\text { (ppm Zr) }\end{array}$ & $\begin{array}{c}\mathrm{ZrCl}_{4} \\
\text { (ppm Zr) }\end{array}$ & $\begin{array}{c}4 \% \mathrm{H}_{2} / \mathrm{N}_{2} \\
(\mathrm{ppm} \mathrm{Zr)}\end{array}$ & $\begin{array}{c}\mathrm{H}_{2} \\
\text { (ppm Zr) }\end{array}$ & $\begin{array}{c}\mathrm{ZrH}_{2} \\
\text { (ppm Zr) }\end{array}$ & $\begin{array}{c}\mathrm{ZrH}_{2} \text { in } 4 \% \\
\mathrm{H}_{2} / \mathrm{N}_{2} \\
\text { (ppm Zr) }\end{array}$ \\
\hline $\mathrm{Cr}$ & 964 & 28 & $<3$ & $<2$ & $<2$ & $<2$ \\
\hline $\mathrm{Fe}$ & 1,651 & 958 & 827 & $<86$ & 91 & $<98$ \\
\hline Co & - & $<2.8$ & $<3$ & $<2$ & $<2$ & $<2$ \\
\hline $\mathrm{Ni}$ & 656 & 4.8 & $<3$ & $<2$ & $<2$ & $<2$ \\
\hline $\mathrm{Nb}$ & 521 & 771 & 1,185 & 1,090 & 18 & 10 \\
\hline Sn & 13,984 & 462 & 14 & 27 & 19 & 14 \\
\hline
\end{tabular}

\section{CONCLUSIONS}

With the completion of the first large-scale chlorination test using high-burnup, relatively short-decayed, high-Nb alloy UNF cladding as the test feed, Zr recovery/purification chlorination tests have now been made with actual UNF cladding with burnups and Nb levels at conditions that bound those typically produced today. At the higher bound (the February 2017 chlorination test), the decontamination from ${ }^{134} \mathrm{Cs}$ and ${ }^{137} \mathrm{Cs}$, which are the major radionuclides in the cladding, was excellent, with essentially $100 \%$ reporting to the residue ash. A filtration/absorber (chabazite zeolite) was used in the $\mathrm{ZrCl}_{4}$ vapor transfer line to prevent entrainment of the relatively low volatility Cs, as well as other low volatility radionuclides, such as $\mathrm{Eu}, \mathrm{Co}, \mathrm{Pu}$, and other transuranium actinides. Uranium, was also likely present as low volatility oxide, but the mass analysis indicated a small portion in the $\mathrm{ZrCl}_{4}$ product; however, this may have been caused by sample contamination. The major finding was confirmation of the presence of high 
concentrations of volatile species of ${ }^{94} \mathrm{Nb}$ and ${ }^{125} \mathrm{Sb}$ in the $\mathrm{ZrCl}_{4}$ product, making the product radiation dose sufficiently high enough to require shielding for the subsequent purification step. In comparison, previous tests of low-burnup long-decayed Sn-based UNF cladding showed no significant radiation dose, even when the chlorination was made by chemical decladding of an intact fuel rod sample.

Based on the project findings so far, future emphasis must be placed on (1) developing a modified operating procedure that minimizes the ${ }^{125} \mathrm{Sb}$ and ${ }^{94} \mathrm{Nb}$ contamination in the $\mathrm{ZrCl}_{4}$ product (and consequently the radiation dose); (2) testing in-cell (shielded) purification of the $\mathrm{ZrCl}_{4}$ product using some of the methods found in the Nuclear Energy University Program studies; and (3) a large-scale chemical decontamination of PWR UNF with burnup and decay times that are more typical of current commercial reactor UNF (such a UNF rod is currently available at ORNL from the mixed oxide lead test assembly post-irradiation evaluation project). The emphasis on chemical decladding is a key step in the advanced head-end process for future reprocessing and in the pretreatment process previously proposed ${ }^{\mathrm{R} 4}$ to minimize the possibility of cladding degradation in long-term storage of UNF intended for direct disposal.

\section{REFERENCES}

1. C. Eysseric, G. Ferlay, A. Salvatores, L. Boucher, J. Lovidon, J. Lamontagne, and M. Bertaux, "Examination and Characterization Methods Applied to Irradiated Fuel Claddings in Atalante Facility,” poster and abstract presented at ATALANTE 2012 International Conference on Nuclear Chemistry for Sustainable Fuel Cycles in Elsevier Procedia Chemistry 7 (2012).

2. E. D. Collins, G. D. Del Cul, B. B. Spencer, R. R. Brunson, and R. D. Hunt, "R\&D Progress on Recovery/Recycle of Zirconium from Used Fuel Cladding,” Transactions of 2015 American Nuclear Society Winter Meeting (Nov. 2015).

3. D. F. McLaughlin and T. L. Francis, Recycle of Zirconium from Used Nuclear Fuel Cladding: Chlorination Process Development and Design, IDIQ Subtask 2, Westinghouse Rep. No. EPTWZ-14-004, Rev. 1 (June 2014).

4. J. C. Bresee, A. R. Griffith, E. D. Collins, R. T. Jubin, G. D. Del Cul, and B. B. Spencer, “Chemical Pre-Treatment of Used Fuel for Long-Term Storage,” paper presented at ATALANTE 2012 International Conference on Nuclear Chemistry for Sustainable Fuel Cycles in Elsevier Procedia Chemistry 7 (2012) 72-76. 
Completion of a Chlorination Test Using 250 grams of High-Burnup Used Fuel Cladding from a North Anna Pressurized Water Reactor

This page is intentionally left blank. 